\title{
Separating autotrophic respiration due to roots from soil heterotrophic respiration in an agroforestry parkland system in Saponé, Burkina Faso
}

\author{
H.R BAZIÉ ${ }^{1,2^{*}}$, J. SANOU ${ }^{2}$, Z. GNANKAMBARY ${ }^{3}$, P.P. SOMÉ ${ }^{1}$, \\ G. ZOMBRÉ $^{1}$ and J. BAYALA ${ }^{4}$ \\ ${ }^{1}$ Université de Ouagadougou, Unité de Formation et Recherche en Sciences de la Vie et de la Terre - 03 BP \\ 7021, Ouagadougou 03, Burkina Faso. \\ ${ }^{2}$ Institut de l'Environnement et de Recherches Agricoles, Département de Productions Forestières, \\ 03 BP 7047 Ouagadougou 03, Burkina Faso. \\ ${ }^{3}$ Institut de l'Environnement et de Recherches Agricoles, Département de Gestion des Ressources Naturelles et \\ Systèmes de Production, 01 BP 476 Ouagadougou 01, Burkina Faso. \\ ${ }^{4}$ World Agroforestry Centre (ICRAF), ICRAF-WCA/Sahel Node, BP E5118 Bamako, Mali. \\ *Corresponding author; E-mail: baziehugues@yahoo.fr ; baziehugues@gmail.com; Tel: (226) 70235632
}

\begin{abstract}
Soil respiration is the largest component of ecosystem respiration but little is known about it and its components in parkland systems. We therefore conducted an experiment to estimate the amount of $\mathrm{CO}_{2}$ respired and to partition it into soil, tree root and crop root contributions in parkland systems in Burkina Faso. Three factors effects were estimated: pruning, species and presence of tree canopy. Pruning showed no significant effect on soil respiration. The soil respiration was significantly higher under Parkia biglobosa (1.54 $\mathrm{g} \mathrm{CO}_{2} \mathrm{~m}^{-2} \mathrm{~h}^{-1}$ against 0.93 in the open area) than under Vitellaria paradoxa $\left(0.98 \mathrm{~g} \mathrm{CO}_{2} \mathrm{~m}^{-2} \mathrm{~h}^{-1}\right.$ against 0.52 in the open area). The autotrophic respiration associated with the $P$. biglobosa system due to sorghum roots was $0.37 \mathrm{~g} \mathrm{CO}_{2} \mathrm{~m}^{-2} \mathrm{~h}^{-1}$ and due to tree roots was 0.61 . For the $V$. paradoxa system, the figures were $0.13 \mathrm{~g} \mathrm{CO}_{2} \mathrm{~m}^{-2}$ $\mathrm{h}^{-1}$ for sorghum roots and 0.46 for tree roots. We observed higher $\mathrm{CO}_{2}$ emissions from under trees crowns than in open areas owing to higher tree-root respiratory activities, and higher water and organic matter contents. However, further studies are needed to discover if these low values of soil $\mathrm{CO}_{2}$ fluxes from parklands translate into higher amounts of carbon fixed than emitted taking into consideration the seasonal variations.
\end{abstract}

(C) 2014 International Formulae Group. All rights reserved.

Keywords: Carbon balance, $\mathrm{CO}_{2}$ flux, carbon-sink, carbon-source.

\section{INTRODUCTION}

In the Sahel, the traditional parkland systems (integrated crop-tree systems), which are the main providers of food, nutrition, income, and environmental services, are rapidly degrading; woody biodiversity and cover are being lost and soil fertility is declining from already low levels because of exhaustive cropping practices and soil erosion (Bationo et al., 2003). The restoration and protection of these Sahelian parklands appears to be vital for the future welfare of over 43 
million people living in the semi-arid drylands of West Africa (Kandji et al., 2006). Nevertheless, there is a lack of data on the optimal functioning of parklands or their alternatives, particularly under changing climatic and socio-economic conditions (Bayala et al., 2011). As the main production systems of the Sahel, parklands may play a key role in carbon balance in the region. The carbon balance of parklands and similar ecosystems is the net result of $\mathrm{CO}_{2}$ fixation by photosynthesis occurring above-ground and the release of carbon as $\mathrm{CO}_{2}$, notably from the below-ground compartment through the respiratory activities of plant roots, their symbiotic mycorrhizal fungi, and the freeliving microbial and faunal populations of the soil (Högberg et al., 2001; Jia et al., 2006). Soil respiration is the largest component of ecosystem respiration and is an indicator of ecosystem metabolism (Ryan and Law, 2005). Because autotrophic and heterotrophic activity below-ground are controlled by substrate availability, soil respiration is strongly linked to plant metabolism, photosynthesis, and litterfall. Roots and associated mycorrhizal fungi are responsible for roughly half of soil respiration, with much of the remainder derived from decomposition of recently produced root and leaf litter (Ryan and Law, 2005). Therefore, changes in the belowground carbon pools can have a major impact on carbon storage in terrestrial ecosystems and alter carbon flux to the atmosphere. Thus, knowledge about the amount of $\mathrm{CO}_{2}$ emitted in a given agroecosystem, as well as its components, has practical implications in terms of designing the most appropriate management options for parkland systems. The contribution of each component to soil respiration needs to be understood in order to evaluate the implications of environmental change on soil carbon cycling and sequestration (Hanson et al., 2000; Wang et al., 2005).

However, studies of root respiration have in large part dealt with forest ecosystems and little research has been done in agroecosystems like the parkland systems of the West African Sahel. Therefore, the aim of the present study was to estimate soil respiration and to separate contributions of autotrophic respiration from trees, autotrophic respiration from crops, and heterotrophic respiration as key components of the respiratory activities of the global carbon balance of such parkland systems. Specifically, the study aimed at assessing the impact of tree canopy of the two main parkland species of Burkina Faso, Parkia biglobosa and Vitellaria paradoxa, on the contribution of soil, tree roots, and crop roots to $\mathrm{CO}_{2}$ flows. Our assumption was that the association of trees and crops would lead to higher $\mathrm{CO}_{2}$ release under trees than in the open.

Separating autotrophic and heterotrophic contributions to soil respiration is an important first step because only organic material consumed by heterotrophs can be stored as soil carbon whereas autotrophic respiration is rapidly released from the soil. In addition, autotrophic and heterotrophic respiration may respond differently to environmental factors (Högberg et al., 2001). Various methods have been tested to separate autotrophic and heterotrophic contributions to soil respiration (Högberg et al., 2001; Kuzyakow, 2002), notably by comparing reference plots with plots where transport of recently assimilated carbon to the soil has been excluded, either by girdling the aboveground component or by excluding roots (usually by trenching). For the present study, trenching using PVC pipes to exclude roots was chosen owing to its simpler implementation. 
The objective of the study was to estimate the respired amount of $\mathrm{CO}_{2}$ and its partitioning into soil, tree root, and crop root contributions in a parkland system in Burkina Faso. We also tested for differences between two common parkland tree species and the effect of tree-canopy pruning. The two studied species were selected because they are the most dominant tree species in the parkland systems of the study area and the effect of pruning was included because it is the easiest silvicultural practice for the rejuvenation of fruit trees (Bayala, 2002; Bayala et al., 2008).

\section{MATERIALS AND METHODS}

\section{Site and studied materials}

The study was conducted in the parklands around Saponé $\left(12^{\circ} 03^{\prime} \mathrm{N}, 1^{\circ} 43^{\prime}\right.$ $\mathrm{W}$, altitude 200 m.a.s.l), a village located 30 $\mathrm{km}$ south of Ouagadougou, the capital city of Burkina Faso, West Africa (Figure 1). The soils in these parklands are shallow (on average ca. $60 \mathrm{~cm}$ deep), sandy loamy regosols (FAO classification) with very low nutrient contents. The climate is SudanoSahelian, with a single rainy season marked by intermittent rains in April and May, followed by more persistent rainfall from June to October. The rainfall was $715.1 \mathrm{~mm}$ in 2007 and its distribution is shown on Figure 2. In a survey of the vegetation in the study area in 1999, 35 tree species from 27 genera and 17 families were found. The most abundant were $V$. paradoxa (relative frequency $58 \%$, 9.05 individuals $\mathrm{ha}^{-1}$ ) followed by $P$. biglobosa (relative frequency $8 \%, 1.22$ individuals $\mathrm{ha}^{-1}$ ), and the overall density of trees was 15.5 trees ha $^{-1}$ (Bayala, 2002).

The tree species considered in this study of tree-crop interactions were Vitellaria paradoxa C.F. Gaertn (shea, or karité in French) and Parkia biglobosa (Jacq.) Benth (locust bean, or néré in French), because they are the most widespread species in both the particular area in and the Sahel in general.
Previous studies on the same species and same site showed that $60-70 \%$ of their fine roots $(\leq$ $2 \mathrm{~mm}$ ) were within the top $20 \mathrm{~cm}$ soil layer (Bayala et al., 2004), soil carbon contents under karité $\left(6.43 \pm 0.45 \mathrm{~g} \mathrm{~kg}^{-1}\right)$ and néré $\left(5.65 \pm 0.27 \mathrm{~g} \mathrm{~kg}^{-1}\right)$ were significantly higher than in the open area $\left(4.09 \pm 0.26 \mathrm{~g} \mathrm{~kg}^{-1}\right)$ (Bayala et al., 2006) and higher soil humidity and temperature were observed by Jonsson et al. (1999).With the help of field owners from the village, 16 mature and healthy trees of each species, spaced at least $40 \mathrm{~m}$ apart, were randomly selected. As these are parkland and not plantation trees, they are dispersed, isolated, not regularly distributed and of different unknown ages. Parklands are farmed fields and therefore livestock is not allowed in except after the harvest. The average diameter of karité was $29.78 \mathrm{~cm}(17.52-46.97 \mathrm{~cm})$ while the average value was $32.96 \mathrm{~cm}$ (16.72$49.04 \mathrm{~cm})$ for néré. The average crown diameter of trees was $9.68 \mathrm{~m}(7.76-11.70 \mathrm{~m})$ and $15.68 \mathrm{~m}(10.46-20.30 \mathrm{~m})$ for karité and néré, respectively. The crop was a local variety of sorghum (Sorghum bicolor (L.) Moench), with a growth period of ca. 130 days, because it is one of the most commonly grown crops in the study area.

\section{Experimental design and data collection}

The following treatments were applied to the selected 16 karité and 16 néré trees, with the agreement of the farmers who helped select them. Eight tree individuals of each species were pruned in June 2007, by reducing all of the secondary branches to one meter from their bases, while the other eight of each species were left unpruned (as controls). Prunings were removed from under the tree canopy and stock outside the experiment area. A local variety of sorghum (Sorghum bicolor) was sown in the second 
half of July 2007 at a spacing of $0.8 \mathrm{~m}$ between and $0.4 \mathrm{~m}$ along rows in the influence zone of each selected tree (vertical projection of the crown to a circle, based on its average diameter in E-W and N-S directions) and in the open area.

Soil respiration was measured with an infrared gas analyser (EGM-4, PP Systems Hitchin, Herts, UK). In a day, the measurements were performed on a variable number of pairs of pruned and unpruned trees of each species. Each pair of the two closest unpruned and pruned trees of either species was considered as replicate as they were experiencing more similar soil conditions. That number varied from one pair of pruned and unpruned trees of each species measured each day to one pair of one species and two pairs of the second species (i.e. four to six individuals per day) and such process was continued until the all 32 (or 16 pairs) were measured. The measurment lasted one day for each pair of pruned and unpruned trees of each species and thus daily measurements are not repeated measurements. Measurements were taken every two hours during the day of measurements from 06:00 to 18:00, from 9 August to 25 September 2007, which is during the rainy season (Figure 2.) and when the sorghum plants were at booting to heading stages. To distinguish crop-plant respiration from the respiration of trees, undisturbed soil was prepared by using a PVC pipe of diameter $15 \mathrm{~cm}$ and length $20 \mathrm{~cm}$ inserted into the bare soil after a sustained period of rain at the beginning of the rainy season. The PVC tubes were maintained free of weeds by continuous hand weeding. Four types of measurement were taken: (1) within the pipe under the tree
(Fh(tree) although tree-root respiration may still exist below the top $20 \mathrm{~cm}$ cut roots of trees by the PVC pipe), (2) outside the pipe under the tree $(\mathrm{Fh}$ (tree) $+\mathrm{Fa}$ (tree) $+\mathrm{Fa}($ crop $)$, (3) within the pipe in the open area (Fh(crop), assuming that respiration from tree roots under the pipe is neglectable), and (4) outside the pipe in the open area (Fh(crop) + $\mathrm{Fa}$ (crop)). These measurements allow the calculation of the contribution of trees and of crops and grasses to soil respiration, even though the approach certainly understimated some of the components as following: $\mathrm{Fa}$ (tree) $=(2)-(3)$ and $\mathrm{Fa}(\mathrm{crop})=(4)-(3)$.

\section{Data analysis}

Nested ANOVA was performed for soil respiration and its components using Genstat 5 release 8.11 (Rothamsted Experimental Station). Due to some large values recorded at 6:00 without plausible explanations of such values and irregular observations at 18:00, the data of these two times were excluded from the analysis. As all trees were not measured the same day, we have included date as we were expecting observations of the same date to be correlated. A multifactorial model was used, taking into consideration the following factors: date, tree, zone, position and hour for the blocks in the one hand and in the other hand species ( $P$. biglobosa and V. paradoxa), pruning (pruned and unpruned), zone (under tree and open area), isolation (within the pipe under the tree, within the pipe in open area, outside the pipe under the tree, and outside the pipe in open area), and hour as well as their interactions. Treatments that proved to be different at $5 \%$ were further separated using Tukey's test. 


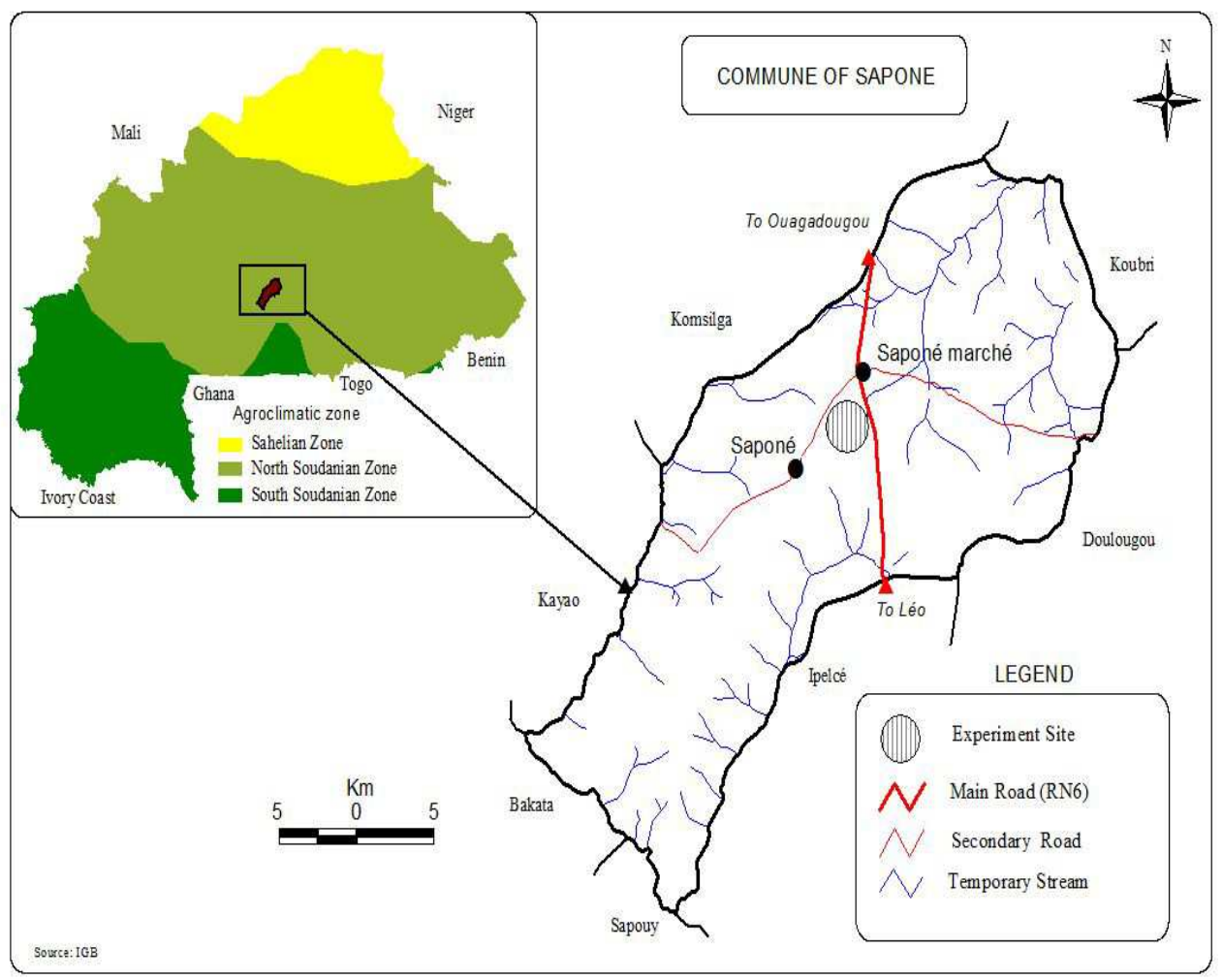

Figure 1: Location of the study site at Saponé in Burkina Faso, West Africa.

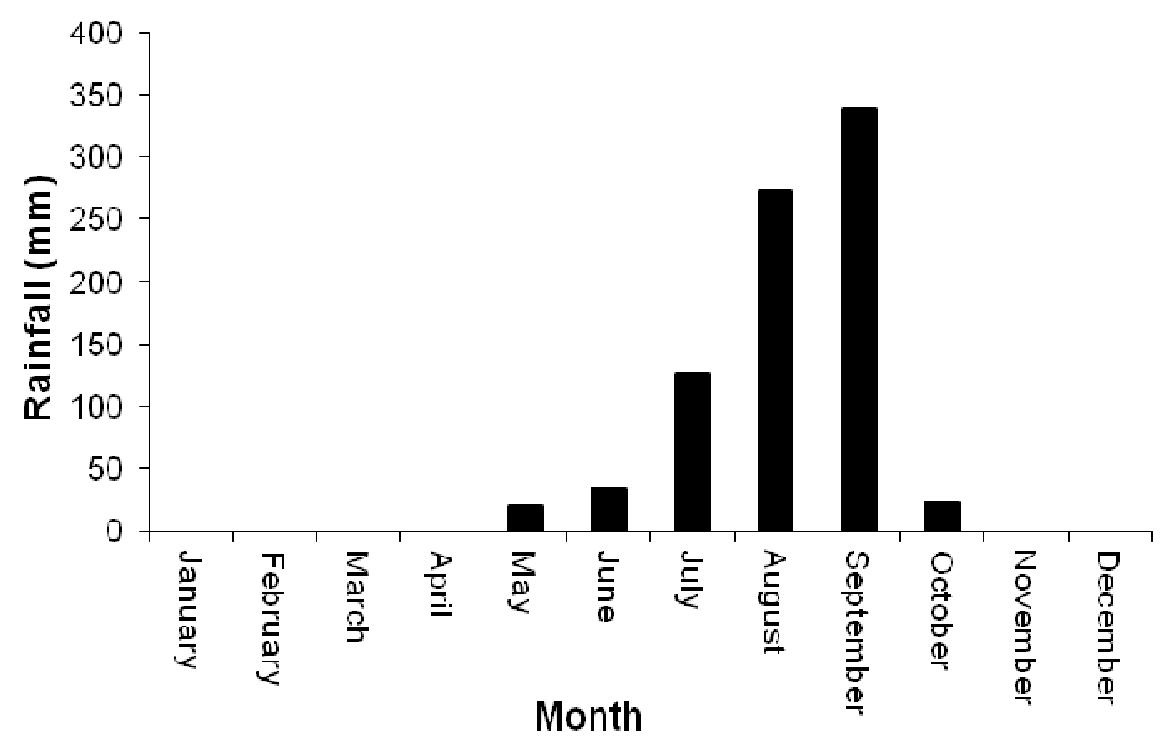

Figure 2: Rainfall in Saponé village, Burkina Faso, West Africa, in 2007. 


\section{RESULTS}

No significant interactions were found between the studied factors (Table 1) whereas significant differences were found for the main effects of species, zone and isolation (Table 1 and Figure 3). Thus, it was found that $\mathrm{CO}_{2}$ emission was always significantly higher under $P$. biglobosa (daily average $1.02 \mathrm{~g} \mathrm{CO}_{2}$ $\mathrm{m}^{-2} \mathrm{~h}^{-1}$ ) at any time of the day than in plots with $V$. paradoxa $\left(0.64 \mathrm{~g} \mathrm{CO}_{2} \mathrm{~m}^{-2} \mathrm{~h}^{-1}\right)$. There was a highly significant difference between the respiration under trees $\left(1.05 \mathrm{~g} \mathrm{CO}_{2} \mathrm{~m}^{-2} \mathrm{~h}^{-1}\right)$ and in the open area $\left(0.60 \mathrm{~g} \mathrm{CO}_{2} \mathrm{~m}^{-2} \mathrm{~h}^{-1} ; P<\right.$ 0.001). Carbon emission within the PVC pipe $\left(0.66 \mathrm{~g} \mathrm{CO}_{2} \mathrm{~m}^{-2} \mathrm{~h}^{-1}\right)$ was also significantly lower than outside the pipe $\left(0.99 \mathrm{~g} \mathrm{CO}_{2} \mathrm{~m}^{-2}\right.$ $\left.\mathrm{h}^{-1}\right)$.

From the difference between the values of the $\mathrm{CO}_{2}$ measured outside and inside the
PVC pipe in the open, the autotrophic respiration due to crop roots was estimated to be on average $0.25 \mathrm{~g} \mathrm{CO}_{2} \mathrm{~m}^{-2} \mathrm{~h}^{-1}$ and to tree roots was $0.53 \mathrm{~g} \mathrm{CO}_{2} \mathrm{~m}^{-2} \mathrm{~h}^{-1}$. Under $V$. paradoxa, $\mathrm{CO}_{2}$ emission was $0.98 \mathrm{~g} \mathrm{CO}_{2} \mathrm{~m}^{-2}$ $\mathrm{h}^{-1}$ as opposed to $0.52 \mathrm{~g} \mathrm{CO}_{2} \mathrm{~m}^{-2} \mathrm{~h}^{-1}$ in the open area (Figure $3 \mathrm{a}$ ). Thus, the autotrophic respiration due to sorghum roots and tree roots was $0.13 \mathrm{~g} \mathrm{CO}_{2} \mathrm{~m}^{-2} \mathrm{~h}^{-1}$ and $0.46 \mathrm{~g} \mathrm{CO}_{2} \mathrm{~m}^{-2} \mathrm{~h}^{-1}$, respectively. Under $P$. biglobosa, $\mathrm{CO}_{2}$ emission was $1.54 \mathrm{~g} \mathrm{CO}_{2} \mathrm{~m}^{-2} \mathrm{~h}^{-1}$ as opposed to $0.93 \mathrm{~g} \mathrm{CO}_{2} \mathrm{~m}^{-2} \mathrm{~h}^{-1}$ in the open area. Thus, the autotrophic respiration due to sorghum roots and tree roots was $0.37 \mathrm{~g} \mathrm{CO}_{2} \mathrm{~m}^{-2} \mathrm{~h}^{-1}$ and 0.61 $\mathrm{g} \mathrm{CO}_{2} \mathrm{~m}^{-2} \mathrm{~h}^{-1}$, respectively. In summary, the roots of $P$. biglobosa emitted more $\mathrm{CO}_{2}$ than those of $V$. paradoxa, as did the sorghum roots under P. biglobosa compared to those under $V$. paradoxa.

Table 1: Nested ANOVA of $\mathrm{CO}_{2}$ emitted $\left(\mathrm{g} \mathrm{CO}_{2} \mathrm{~m}^{-2} \mathrm{~h}^{-1}\right)$ with the factors: date, tree, zone, position, and time for both karité (Vitellaria paradoxa) and néré (Parkia biglobosa) in a parkland system in Saponé village, Burkina Faso, West Africa.

\begin{tabular}{lcccc}
\hline Source of variation & d.f. & m.s. & v.r. & F pr. \\
\hline Date stratum & 1 & 7.5050 & 0.75 & 0.437 \\
Species & 4 & 10.0729 & & \\
Residual & & & & \\
Date.Tree stratum & $\mathbf{1}$ & $\mathbf{1 5 . 3 5 7 1}$ & $\mathbf{6 . 1 0}$ & $\mathbf{0 . 0 2 1}$ \\
\hline Species & 1 & 2.6291 & 1.04 & 0.318 \\
Pruning & 1 & 1.9141 & 0.76 & 0.392 \\
Species.pruning & 23 & 2.5186 & 1.54 & \\
Residual & & & & \\
Date.Tree.Zone stratum & $\mathbf{1}$ & $\mathbf{3 2 . 8 0 6 3}$ & $\mathbf{2 0 . 0 5}$ & $<.001$ \\
\hline Zone & 1 & 1.4861 & 0.91 & 0.349 \\
Zone.Species & 1 & 0.1328 & 0.08 & 0.778 \\
Zone.Pruning & 1 & 1.8533 & 1.13 & 0.296 \\
Zone.Species.Pruning & 28 & 1.6362 & 1.07 & 0.784 \\
Residual & & & & 0.839 \\
Date.Tree.Zone.Position stratum & & & & \\
\hline Isolation & 1 & $\mathbf{1 7 . 7 7 5 6}$ & $\mathbf{1 1 . 5 8}$ & $\mathbf{0 . 0 0 1}$ \\
Zone.Isolation & 1 & 1.0775 & 0.70 & 0.406 \\
Species.Isolation & 1 & 1.6810 & 1.10 & 0.300 \\
Pruning.Isolation & 1 & 0.1161 & 0.08 & 0.784 \\
Zone.Species.Isolation & & 0.0640 & 0.04 & 0.83 \\
& & & & \\
& & & & \\
\end{tabular}




\begin{tabular}{lcccc} 
Zone.Pruning.Isolation & 1 & 0.0166 & 0.01 & 0.918 \\
Species.Pruning.Isolation & 1 & 0.1769 & 0.12 & 0.735 \\
Residual & 57 & 1.5344 & 6.05 & \\
\hline Date.Tree.Zone.Position.Hour stratum & & & & \\
Hour & 4 & 0.1763 & 0.69 & 0.596 \\
Zone.Hour & 4 & 0.2036 & 0.80 & 0.524 \\
Hour.Species & 4 & 0.3064 & 1.21 & 0.307 \\
Hour.Pruning & 4 & 0.1602 & 0.63 & 0.641 \\
Hour.Isolation & 4 & 0.0538 & 0.21 & 0.932 \\
Zone.Hour.Species & 4 & 0.1651 & 0.65 & 0.627 \\
Zone.Hour.Puning & 4 & 0.2229 & 0.88 & 0.477 \\
Hour.Species.Pruning & 4 & 0.1696 & 0.67 & 0.614 \\
Zone.Hour.Isolation & 4 & 0.1666 & 0.66 & 0.623 \\
Hour.Species.Isolation & 4 & 0.1960 & 0.77 & 0.544 \\
Hour.Pruning.Isolation & 4 & 0.1572 & 0.62 & 0.649 \\
Residual & 468 & 0.2538 & & \\
Total & $\mathbf{6 3 9}$ & & & \\
\hline
\end{tabular}

d.f. $=$ degrees of freedom, m.s. = mean square, $v . r=\mathrm{F}$ variance ratio, $\mathrm{F}$ pr. $=$ probability of rejecting null hypothesis.

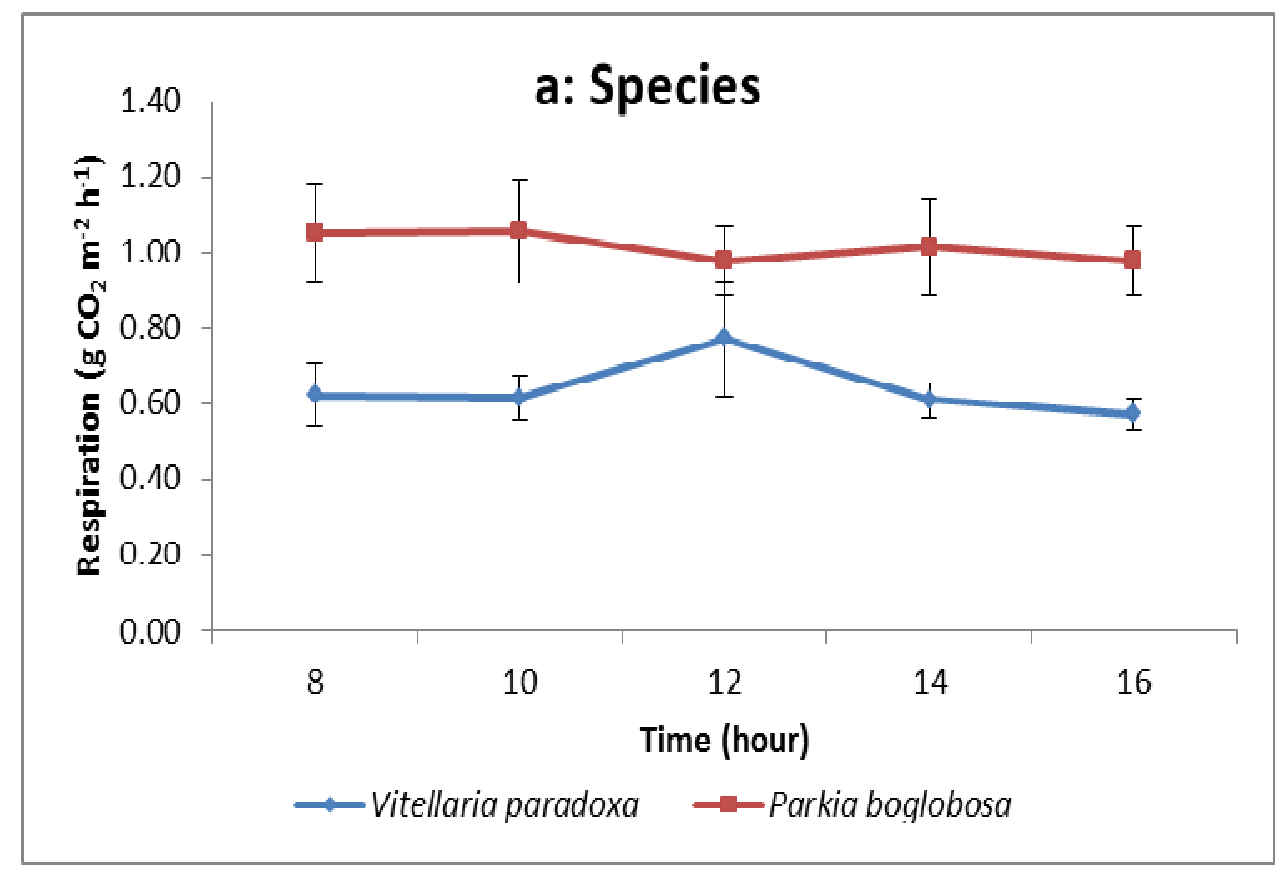




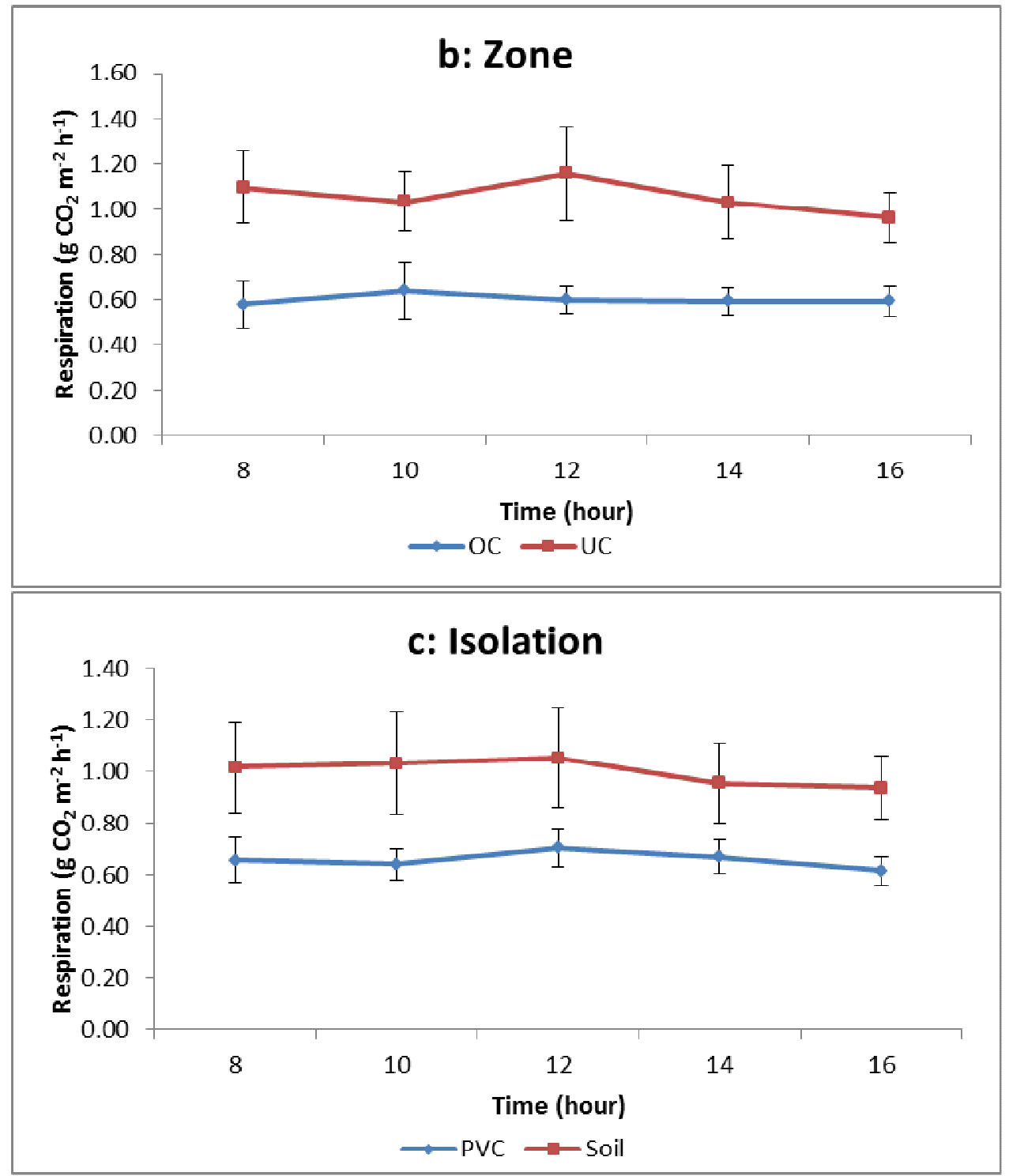

Figure 3: Diurnal patterns of soil $\mathrm{CO}_{2}$ emission $\left(\mathrm{g} \mathrm{CO}_{2} \mathrm{~m}^{-2} \mathrm{~h}^{-1}\right)$ for both karite (Vitellaria paradoxa) and néré (Parkia biglobosa) in a parkland system in Saponé village, Burkina Faso, West Africa. $\mathrm{OC}=$ outside canopy; $\mathrm{UC}=$ under canopy; $\mathrm{PVC}=$ within $\mathrm{PVC}$ pipe; Soil $=$ outside $\mathrm{PVC}$ pipe; $\mathrm{n}=$ means of 64 observations.

\section{DISCUSSION}

Within the zone of influence of the two studied species, soil respiration ranged on average from $0.98 \mathrm{~g} \mathrm{CO}_{2} \mathrm{~m}^{-2} \mathrm{~h}^{-1}$ to $1.54 \mathrm{~g} \mathrm{CO}_{2}$ $\mathrm{m}^{-2} \mathrm{~h}^{-1}$, which is lower than the range of 4.99 $\mathrm{g} \mathrm{CO}_{2} \mathrm{~m}^{-2} \mathrm{~h}^{-1}$ to $11.54 \mathrm{~g} \mathrm{CO}_{2} \mathrm{~m}^{-2} \mathrm{~h}^{-1}$ reported by Wang et al. (2005) for mixed $\mathrm{C}_{3} / \mathrm{C}_{4}$ grassland. Such a difference might be due to differences in net primary productivity and thus in the amount of recently produced root and leaf litter (Ryan and Law, 2005) and/or to differences in environmental conditions (Hanson et al., 2000; Högberg et al., 2001). This must also be due to $\mathrm{P}$ limitation and this hypothesis is consistent with the finding of Gnankambary et al. (2008) who observed that utilization of $\mathrm{C}$ by soil microbes in soils from under and outside canopies of Faidherbia 
albida and $V$. paradoxa (karité) was limited firstly by P-fixation. Trenching methods may underestimate root respiration because they initially increase the substrate supply for microbial respiration (Bhupinderpal et al., 2003) and small-area trenched plot is a source of some uncertainties on the accuracy and interpretation of the results (Jassal and Black, 2006). Trenching probably excludes $60-70 \%$ of tree roots for the two species and $70 \%$ of sorghum roots (Bayala et al., 2004); and probably the same proportions of root respiration. Soil carbon content is one of the key factors to consider when assessing the sustainability of cropping systems and their effect on the environment; particularly in the Sahel, where kaolinite is the main type of clay in the soils (Bationo and Buerkert 2001; Bayala et al., 2006). The abovementioned values were obtained during the rainy season, which is the peak period of vegetation growth, and lower values might be expected during the dry season when vegetation is less active.

The autotrophic respiration was found to be $0.46 \mathrm{~g} \mathrm{CO}_{2} \mathrm{~m}^{-2} \mathrm{~h}^{-1}$ (47\% of total respiration) for $V$. paradoxa roots and $0.13 \mathrm{~g}$ $\mathrm{CO}_{2} \mathrm{~m}^{-2} \mathrm{~h}^{-1}$ (13\% of total respiration) for the associated sorghum roots. The figures were $0.61 \mathrm{~g} \mathrm{CO}_{2} \mathrm{~m}^{-2} \mathrm{~h}^{-1}$ (40\% of total respiration) and $0.37 \mathrm{~g} \mathrm{CO}_{2} \mathrm{~m}^{-2} \mathrm{~h}^{-1} \quad(24 \%$ of total respiration) for $P$. biglobosa roots and the associated sorghum roots, respectively. Despite the difference in absolute values of the root respiration between the two species, their relative values to the total amount of soil respiration varied less $(40-47 \%$ of total respiration). This is within the range of 10$90 \%$ but may represent an underestimation of this component because of the increased contribution of $\mathrm{CO}_{2}$ to the measured efflux in the root exclusion plot from below the root exclusion depth (Jassal and Black, 2006). This release of carbon from living plant roots, their mycorrhizal fungi, and other root-associated microbes is directly driven by recent photosynthesis as the flux of current assimilates to the root is a key driver of soil respiration (Ekblad and Högberg, 2001; Högberg et al., 2001).

Higher $\mathrm{CO}_{2}$ emission was observed under $P$. biglobosa than under $V$. paradoxa and the difference was largely due to root respiration. This may be due to a higher leaf area index for $P$. biglobosa, which would result in a higher gross primary production (GPP) and a higher root respiration. Indeed, it has been reported that $P$. biglobosa has a larger leaf area $\left(1460 \mathrm{~m}^{2}\right.$ tree ${ }^{-1}$ versus $360 \mathrm{~m}^{2}$ tree $^{-1}$ ) than $V$. paradoxa (Bayala, 2002), higher fine-root $\left(0.196 \mathrm{~cm} \mathrm{~cm}^{-3}\right.$ versus 0.123 $\mathrm{cm} \mathrm{cm} \mathrm{cm}^{-3}$, means of three cropping seasons 1999-2001) density (Bayala et al., 2004), and faster canopy recovery (0.9 $\mathrm{m}_{\text {year }}{ }^{-1}$ versus $0.7 \mathrm{~m}$ year $^{-1}$, means of five years 2000-2005) after pruning (Bayala et al., 2008), all of which are indicators of higher growth reserves and GPP. Higher $\mathrm{CO}_{2}$ efflux under $P$. biglobosa may also be due to more rapid mineralization of tree litter and to higher soil fertility (Bayala et al., 2002, 2006). According to Gnankambary et al. (2008), the decomposition rate depends on the initial chemical composition of the litter and thus on its $\mathrm{C} / \mathrm{N}$ ratio as a low value of this ratio leads to faster decomposition. Bayala et al. (2005) and Bazié (2006) reported $\mathrm{C} / \mathrm{N}$ values of 31 to 64 for the litter of $V$. paradoxa against only 23 for the litter of $P$. biglobosa. These figures explain why the leaves of the latter decomposed faster than those of the former releasing in three months $80 \%, 90 \%$ and $75 \%$ of their $\mathrm{N}, \mathrm{P}$ and $\mathrm{K}$ contents versus $40 \%, 70 \%$ and $80 \%$ for karité, respectively (Bayala et al., 2005). Furthermore, higher respiration under $P$. biglobosa may also be related to its infection by endomycorrhizae and the formation of nodules as reported by Tomlinson et al. (1995). Respiratory activity is strongly affected by photosynthetic activity of the plant and the existence of symbiotic associations with rhizobia and mycorrhizae (Högberg et al., 2001). However, as the activity of such micro-organisms is dependent on carbon and soil-nutrient content, one can hypothesize that limitations to carbon and 
nitrogen availability may explain the differences in $\mathrm{CO}_{2}$ respiration between the studied tree species as well as between respiration under trees and in the open area. Indeed, leaf litter and tree roots under the crowns increases soil organic matter as tree contribution to soil $\mathrm{C}$ was found be $4.01 \pm 0.71$, $3.02 \pm 0.53,1.53 \pm 0.10 \mathrm{~g} \mathrm{~kg}^{-1}$ by Bayala et al. (2006) under under karité, néré and in the open area, respectively in the same site. The hypothesis of faster mineralization under trees in comparison to the open area is consistent with higher soil microbial and enzymatic activities found under karité as reported by Boffa (1999). In addition, Gnankambary et al. (2008) observed that parkland canopies of $F$. albida and $V$. paradoxa influenced the availability of $\mathrm{N}$ and $\mathrm{P}$ for microbes.

The $\mathrm{CO}_{2}$ emission increased from 0.84 $\mathrm{g} \mathrm{CO}_{2} \mathrm{~m}^{-2} \mathrm{~h}^{-1}$ at 08:00 to $0.87 \mathrm{~g} \mathrm{CO}_{2} \mathrm{~m}^{-2} \mathrm{~h}^{-1}$ at 12:00 before decreasing to $0.78 \mathrm{~g} \mathrm{CO}_{2} \mathrm{~m}^{-2} \mathrm{~h}^{-1}$ at 16:00. If soil respiration under tree crowns is driven by primary production, as stated by Högberg et al. (2001), $\mathrm{CO}_{2}$ emission should be related to transpiration, perhaps with a time-lag. Peak transpiration for both tree species is between 10:00 and 14:00 (Bayala et al., 2002, 2009), suggesting a possible time lag of 14 to $18 \mathrm{~h}$ between the period of high transpiration and the period of high respiration (somewhere between 22:00 and 08:00). Such a time-lag may be due to the long transport distance from leaves to roots and the large carbohydrate storage capacity, which serves as a capacitor that can decouple photosynthesis and below-ground processes (Bhupinderpal et al., 2003). In accordance with this hypothesis, peak respiration for sorghum was between 10:00 and 14:00, indicating a short time-lag, which would be expected due to the shorter transport distance from canopy to roots and lower storage capacity of this species. However, to more precisely understand and explain this diurnal pattern, a day and night study is needed. The lack of a significant difference in $\mathrm{CO}_{2}$ emission between unpruned and pruned trees is in disagreement with what would have been expected as a result of the higher soil temperatures caused by the removal of the canopy (Fang and Moncrieff, 2001; Janssens and Pilegaard, 2003). Unfortunately, the current study failed to produce data on temperature parameter to elucidate this aspect.

\section{Conclusion}

Soil respiration under tree crowns was not significantly affected by pruning and that is in disagreement with what was expected indicating the need for future investigations. Besides, higher $\mathrm{CO}_{2}$ emission was recorded under P. biglobosa $\left(1.54 \mathrm{~g} \mathrm{CO}_{2} \mathrm{~m}^{-2} \mathrm{~h}^{-1}\right)$ than under $V$. paradoxa $\left(0.98 \mathrm{~g} \mathrm{CO}_{2} \mathrm{~m}^{-2} \mathrm{~h}^{-1}\right)$. This seems to be in great part due to higher autotrophic root respiration in $P$. biglobosa $\left(0.61 \mathrm{~g} \mathrm{CO}_{2} \mathrm{~m}^{-2} \mathrm{~h}^{-1}\right)$ than in $V$. paradoxa $(0.46$ $\left.\mathrm{g} \mathrm{CO}_{2} \mathrm{~m}^{-2} \mathrm{~h}^{-1}\right)$. In addition, more $\mathrm{CO}_{2}$ was emitted under tree crowns than in the open area, corroborating the argument of higher root respiratory activities under tree crowns. Overall, the $\mathrm{CO}_{2}$ emissions for this parkland system were found to be much lower than what has been reported in the literature, probably due to the low net primary productivity of this particular parkland area.

\section{ACKNOWLEDGEMENTS}

This study was funded by a grant awarded to the last author by the International Foundation for Science (IFS). We thank the farmers in Saponé for their permission and participation in the field experiment. We acknowledge Belem Achille for field assistance, and anonymous reviewers for comments on the manuscript.

\section{REFERENCES}

Bationo A, Buerkert A. 2001. Soil organic carbon management for sustainable land use in Sudano-Sahelian West Africa. Nutr. Cycl. Agroecosys., 61: 131-142.

Bationo A, Traore Z, Kimetu J, Bagayoko M, Kihara J, Bado V, Lompo M, Tabo R, Koala S. 2003. Cropping systems in the Sudano-Sahelian zone: Implications on soil fertility management. From: 
http://www.syngentafoundation.org/db/1/ 432.pdf.

Bayala J. 2002. Trees crown pruning as management tool to enhance the productivity of parkland in West Africa. Ph.D. Thesis, School of Agricultural and Forest Sciences, University of Wales, Bangor UK.

Bayala J, Balesdent J, Marol C, Zapata F, Teklehaimanot Z, Ouedraogo SJ. 2006. Relative contribution of trees and crops to soil carbon content in a parkland system in Burkina Faso using variations in natural ${ }^{13} \mathrm{C}$ abundance. Nutr. Cycl. Agroecosys., 76: 193-201.

Bayala J, Kalinganire A, Tchoundjeu Z, Sinclair F, Garrity D. 2011. Conservation Agriculture with Trees (CAWT) in the West African Sahel: A review. Occasional Paper 14. World Agroforestry Centre, West and Centre Regional Office, Sahel Node, Bamako, Mali and World Agroforestry Centre, Nairobi, Kenya.

Bayala J, Mando A, Teklehaimanot Z, Ouedraogo SJ. 2005. Nutrient release from decomposing leaf mulches of karité (Vitellaria paradoxa) and néré (Parkia biglobosa) under semi-arid conditions in Burkina Faso, West Africa. Soil Biol. Biochem., 37: 533-539.

Bayala J, Ouédraogo SJ, Ong CK. 2009. Early growth performance and water use of planted West African provenances of Vitellaria paradoxa C.F. Gaertn (karité) in Gonsé, Burkina Faso. Agrofor. Syst., 75: $117-127$.

Bayala J, Ouedraogo SJ, Teklehaimanot Z. 2008. Rejuvenating indigenous trees in agroforestry parkland systems for better fruit production using crown pruning. Agrofor. Syst., 72: 187-194.

Bayala J, Teklehaimanot Z, Ouedraogo SJ. 2004. Fine root distribution of pruned trees and associated crops in a parkland system in Burkina Faso. Agrofor. Syst., 60: $13-26$.

Bayala J, Teklehaimanot Z, Ouedraogo SJ. 2002. Millet production under crown pruned trees in a parkland system in Burkina Faso. Agrofor. Syst., 54: 203214.

Bazié HR. 2006. Effet de la fertilisation minérale sur la décomposition d'un mélange de feuilles dans un parc agroforestier à Boni. Mémoire d'ingénieur du développement rural. Université Polytechnique de BoboDioulasso/Institut de Développement Rural, Bobo-Dioulasso, Burkina Faso.

Bhupinderpal-Singh, Nordgren A, OttossonLöfvenius M, Högberg MN, Mellander PE, Högberg P. 2003. Tree root and soil heterotrophic respiration as revealed by girdling of boreal Scots pine forest: Extending observations beyond the first year. Plant Cell Environ., 26: 1287-1296.

Boffa JM. 1999. Agroforestry Parklands in Sub-Saharan Africa. FAO Conservation Guide 34. Food and Agriculture Organization of the United Nations: Rome, Italy.

Ekblad A, Högberg P. 2001. Natural abundance of ${ }^{13} \mathrm{C}$ in $\mathrm{CO}_{2}$ respired from forest soils reveals speed of link between tree photosynthesis and root respiration. Oecologia, 127: 305-308.

Fang C, Moncrieff JB. 2001. The dependence of soil $\mathrm{CO}_{2}$ efflux on temperature. Soil Biol. Biochem., 33: 155-165.

Gnankambary Z, Ilstedt U, Nyberg G, Hien V, Malmer A. 2008. Nitrogen and phosphorus limitation of soil microbial respiration in two tropical agroforestry parklands in the south-Sudanese zone of Burkina Faso: the effects of tree canopy and fertilization. Soil Biol. Biochem., 40: 350-359.

Hanson PJ, Edwards NT, Garten CT, Andrews JA. 2000. Separating root and soil microbial contributions to soil respiration: A review of methods and observations. Biogeochemistry, 48: 115-146.

Högberg P, Nordgren A, Buchmann N, Taylor AFS, Ekblad A, Högberg MN, Nyberg G, Ottosson-Löfvenius M, Read DJ. 2001. Large-scale forest girdling shows that 
current photosynthesis drives soil respiration. Nature, 411: 789-792.

Janssens IA, Pilegaard K. 2003. Large seasonal changes in Q10 of soil respiration in a beech forest. Global Change Biol., 9: 911-918.

Jassal RS, Black AT. 2006. Estimating heterotrophic and autotrophic soil respiration using small-area trenched plot technique: theory and practice. Agr. For. Meteorol., 140: 193-202.

Jia B, Zhoua G, Wang F, Wang Y, Yuan W, Zhou L. 2006. Partitioning root and microbial contributions to soil respiration in Leymus chinensis populations. Soil Biol. Biochem., 38: 653-660.

Jonsson K, Ong CK, Odongos JCW. 1999. Influence of scattered néré and karité on microclimate, soil fertility and millet yield in Burkina Faso. Exp Agric, 35: 3953.

Kandji ST, Verchot L, Mackensen J, 2006. Climate Change and Variability in the
Sahel Region: Impacts and Adaptation Strategies in the Agricultural Sector. ICRAF/UNEP, Nairobi, Kenya.

Kuzyakov Y. 2002. Separating microbial respiration of exudates from root respiration in non-sterile soils: A comparison of four methods. Soil Biol. Biochem., 34: 1621-1631.

Ryan MG, Law BE. 2005. Interpreting, measuring, and modeling soil respiration. Biogeochemistry, 73: 3-27.

Tomlinson HF, Teklehaimanot Z, Traore A, Olapade E. 1995. Soil amelioration and root symbioses of Parkia biglobosa (Jacq.) in West Africa. Agrofor. Syst., 30: 145-159.

Wang W, Ohse K, Liu J, Mo W, Oikawa T. 2005. Contribution of root respiration to soil respiration in a $\mathrm{C} 3 / \mathrm{C} 4$ mixed grassland. J. Biosci., 30: 507-514. 